\title{
原著
}

\author{
初発乳がん患者に対する \\ 教育的グループ介入の有効性の検討 \\ 一情報への満足度に関して一-
}

福 井 小紀子*

\section{The Effect of Educational Group Intervention on Satisfaction with Information among Japanese Women with Primary Breast Cancer}

\author{
Sakiko Fukui \\ School of Nursing, Tokyo Metropolitan University of Health Sciences
}

キーワード：グループ介入，乳がん，情報への満足度

Key words : group intervention, breast cancer, satisfaction with information

\begin{abstract}
Many studies have pointed out that most cancer patients have unmet informational needs and they are often dissatisfied with information they receive. However, no studies have investigated the effect of informational supports on the satisfaction with information for Japanese cancer patients. The aim of this study was to determine the effect of an educational group intervention in improving satisfaction with information among patients with primary breast cancer in a randomized controlled trial.

The patient selection criteria were age less than 65 years, and surgery undergone within the previous 4-18 months as of the start of the study. We conducted a 6 -week educational group intervention. The intervention consisted of health education, coping skills training, and relaxation. Subjects were assessed for the satisfaction with medical information and psychological information using the Visual Analogue Scale (VAS) at the baseline, at 6 weeks, and at 6 months.

Fifty $(33 \%)$ of the 151 patients participated and were randomized, and $46(30 \%)$ completed the study. The experimental group had significantly higher scores than the controls for the satisfaction with the information about breast cancer $(p=.04)$, stress of having cancer $(p=.0001)$, and coping methods to cancer $(\mathrm{p}=.0001)$, and the satisfaction with total medical services they receive $(\mathrm{p}=.0009)$ over the study period.

The results of this study suggest that a short-term educational group intervention produces significant long-term improvement in the satisfaction with information of Japanese patients with primary breast cancer.
\end{abstract}

*東京都立保健科学大学 


\section{要 旨}

がん患者の情報への満足度は概して低く，その支援策を検討していくことは医療者にとっ て急務である，そこで，本研究では，初発乳がん患者に対して教育的グループ介入を行い， 情報への満足度に関する効果について無作為比較対照試験を用いて検討した。

対象は，年齢65歳以下，術後経過期間 4 18 万月の初発乳がん患者である. 介入内容は 毎週 1 回 90 分，全 6 回，教育，コーピング技能訓練，リラクゼーションの 3 部から構成され るものである. 介入のアウトカムである情報への満足度の評価はベースライン時, 介入 6 週 後, 介入 6 ケ月後の 3 回, Visual Analogue Scaleを用いて行った.

151 例の適格者のうち 50 名 $(33 \%)$ が研究に参加し, 介入群 $(n=25)$ および対照群 $(n=$ 25）に無作為に割り付けられた。6週間の介入により，介入群は対照群に比べ，乳がんに関 する情報 $(\mathrm{p}=.04)$ ，がんによるストレスに関する情報 $(\mathrm{p}=.0001)$ ，がんへの対処法に関す る情報 $(\mathrm{p}=.0001)$ ，および医療全体 $(\mathrm{p}=.0009)$ への満足度が6ヶ月間にわたり有意に改善 した.

\section{緒言}

欧米では，乳がんは罹患数が高く長期生存が 可能な疾患である (Landisら 1998) ことから，乳 がん患者は様々な心理社会的問題を抱えること が多くの研究により指摘されてきた(Fallowfield ら 1990 ; Goldberg ら 1992 ; Ganz 1996 ; Walkerら 1996 ; Spiegel 1997)。 その結果, 過 去 20 年間にこれらの問題に対する支援として教 育的介入を含む心理社会的介入の効果が数多く 検討され，最近のメ夕・アナリシスにより心理 社会的介入はがん患者のQOLの改善に有効であ ると結論づけられた(Meyerら 1995 ; Sheardら 1999).

一方，我が国においても乳がん罹患数は増加 しており(厚生省 1999), 乳がん患者に対する心 理社会的支援の必要性が認識されるようになっ てきている。しかし，米国のグループ支援 ‘I can cope’ (Johnson ら 1982)を我が国に導入した ‘がんを知って歩む会’ (季羽1998)や，“あけぼ の会”，“ソレイユ’ といった乳がん患者を対象 とした患者会 (プリメド社1996)などの実践的な グループ支援は存在するものの，研究的な観点 からがん患者に対するグループ支援の有効性を 無作為比較試験により示した報告は皆無である. がん患者に対して欧米で開発されたグループ介 入法が文化の異なる国々のがん患者に対して有
効であると結論づけることを問題視する報告 (Meyerら 1996)や，文化的差異を考慮せずに日 本人に対して欧米の介入モデルを適用すればそ の効果を最大限に引き出すことはできないこと を指摘する報告 (Tamuraら 1992) が見られるこ とから，我が国のがん患者に対してグループ介 入を施行していく際にはこれらの指摘を考慮し, 介入の効果を検討していくことが必要である.

このような背景から，著者は，欧米でその有 効性が実証されている教育的グループ介入モデ ル(Fawzyら 1990, 1994)を我が国の初発乳がん患 者を対象に行い, その実施可能性を検討し, 我 が国の乳がん患者向けに修正版介入モデルを作 成した(Fukui ら 2000a).さらに, 修正版介入モ デルを用いて無作為比較対照試験によりその効 果を精神的負担とがんへの対処法において示し た(Fukuiら 2000b)。本報告では，がん患者にと って最も重要なニーズは情報伝達であるとレビ ユー論文において結論づけられていること( Ong ら 1995 ; Rees ら 2000), さらに, 情報に対する ニーズは満たされず，情報への満足度はしばし ば低いことが指摘されていること (Fallowfieldら 1986 ；Ongら 2000 ; Reesら 2000) から, 教育的 グループ介入において提供する情報への満足度 に関する効果を無作為比較試験により検討する ことを目的とした。 


\section{方法}

\section{1. 対 象}

国立がんセンター東病院にて1996年 8 月より 1998年 2 月までに手術療法を受けた後，外来通 院をしている初発乳がん患者のうち，1) 年齢65 歳以下；2)術後経過期間 4 18 ケ月；3) 再発リ スクが高く，その告知がなされている者 [再発 のリスクの高い症例をリンパ節転移個数が1つ以 上，または組織異型度が $2 \sim 3$ を満たすものとし た(Tsudaら 1998) ] ；4）化学療法完了者または 未施行者，5）重篤な精神科的疾患および痴呆を 持たない者；6) 重複がん患者でない者を適格条 件とした。

\section{2. 調查手順}

本研究は国立がんセンター倫理委員会に倫理 審査申請書を提出し，承認を受けて行った。ま た研究参加者から初回アセスメント開始日に研
究の説明を行った上で書面による同意を得た。

最初に，研究の適格例に対して郵送調査を行 い，同封した説明用紙にて研究内容を説明した 上で，研究への参加意思について尋ね，その回 答の返送を要請した。次に, 研究への参加意思 を示した対象 50 名を，乱数表を用いて介入群 (3グループ) と対照群 $(3$ グループ) の 2 群に無作 為に割り付けた。各対象者に電話にて割り付け られたグループとその施行時期を伝えた。

介入群 3 グループに対しては順次介入を実施 した．対照群は待機リスト対照群とし，3回のア セスメントが終了したのち介入を施行した。本 研究デザインを用いた理由は, 対照群への倫理 的配慮が必要との指摘(Greerら 1992 ; Bottomly 1997）を考慮したためである.

なお，アセスメントは，介入群にはベースラ イン時 (介入実施前), 介入 6 週後, 介入 6 ケ月後 の計 3 回, 待機リスト対照群には介入群と同時 期に行った(図1).

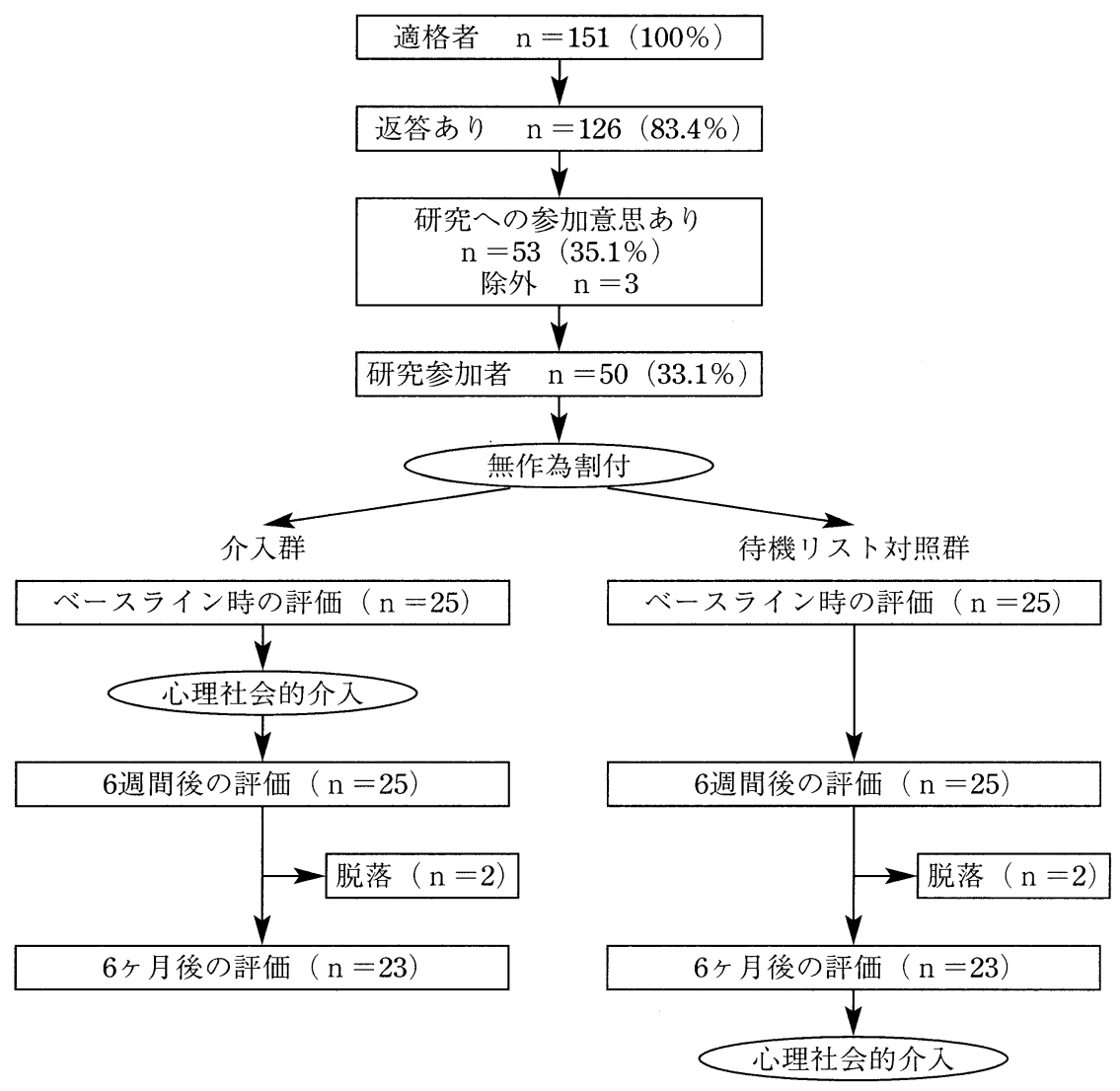

図1 研究参加状況 


\section{3. 介入モデル}

教育的グループ介入とは，2夕イプ(教育的介 入および心理療法的介入)に大別できる心理社会 的介入の1つのタイプであり，誤認により生じる 精神的負担の軽減，および，がんに罹患するこ とにより生じる心理社会的問題に対する前向き な対処法の習得を目的とした正しい情報の提供 および教育を行う支援法である(Massieら 1993 ; Fawzyら 1990, 1994). 本研究では, 正し い情報の提供および教育が行われることにより 情報への満足度が高まり，その結果として精神 的負担が軽減され，また前向きな対処法が習得 されると考え，アウトカムとして情報への満足 度を設定した。本介入は，がん治療に携る医療 専門職による指導が主体で，内容が構造化され ている短期間のグループ設定のものと定義され る(Goldonら 1980).

本研究では, Fawzyら $(1990,1994)$ によるモデ ルを日本の乳がん患者向けに修正した教育的介 入モデル(Fukui 2000a)を使用した(表1)。これ は, 週1回 1.5 時間, 計6回, 1) 教育, 2) コーピ ング技能訓練，3）リラクゼーションからなるも ので, 1 グループを参加者 $6 \sim 10$ 人と 2 人の治療 者 (看護職, 精神科医, 臨床心理士, およびソ ーシャル・ワーカー)で構成した。教育セッショ
ンにおいては，第1回を予備調査における参加者 の意向からリラックスして介入に参加できるよ うにオリエンテーションとした。また，予備調 査にて医学的情報より心理的情報の要望が高か ったため第 $2 \sim 4$ 回に心理学的情報，第 5 回に医 学的情報を提供した。医学的情報に関しては参 加者のニーズに見合う情報提供ができるように Q\&A形式とし, 補足資料として国立がんセンタ 一ホームページ上の ‘国立がんセンターがん情 報サービス：乳がんとは’ (国立がんセンター情 報委員会提供 http://wwwinfo.ncc.go.jp/NCC$\mathrm{CIS} / \mathrm{pub} / \mathrm{sites} / \mathrm{Osj} / \mathrm{breast}$ html）をプリントア ウトしたものを配布した。また毎回講義内容の ハンドアウトを配布した。コーピング技能訓練 のセッションに抒いては，教育セッションで設 定した各回のテーマの教育効果がより引き出せ るように，各回関連性を持つディスカッション のテーマを設定し，コーピングシナリオに基づ いて参加者間でディスカッションを行った。リ ラクゼーションのセッションでは, 毎回20分に わたる漸進的筋弛緩法を実施した。なお，グル ープ間の介入内容の均一性を確保するために, 治療者用マニュアルを作成するとともに，各介 入実施回前後に研究メンバーによるミーティン グを行い, 介入内容の均一性を確認した。

\section{表1 本研究で用いた心理社会的介入モデル}

\begin{tabular}{|c|c|c|}
\hline セッション & $\begin{array}{l}\text { 実施時期 } \\
\text { ( n 回目) }\end{array}$ & 内 \\
\hline \multirow{6}{*}{ I . 教育 } & 1 & オリエンテーション \\
\hline & 2 & 心理学的情報：がんによるストレス \\
\hline & 3 & 心理学的情報：がんへの対処法 \\
\hline & 4 & 再発、再発不安の成り立ち \\
\hline & 5 & 医学的情報：乳がん、治療a） \\
\hline & 6 & 総括 \\
\hline \multirow{6}{*}{ II．コーピング技能訓練b) } & 1 & オリエンテーション \\
\hline & 2 & 診断時の問題 \\
\hline & 3 & 治療中の問題、ボディー・イメージ \\
\hline & 4 & 再発不安への取り組み方 \\
\hline & 5 & 家族、友人、同僚、および医療者との関係 \\
\hline & 6 & 将来への展望 \\
\hline \multirow{2}{*}{ III.リラクゼーション } & 1 & 効果の説明、漸進的筋弛緩法実施, テープ配布 \\
\hline & $2 \sim 6$ & 漸進的筋弛緩法実施 \\
\hline
\end{tabular}

a)：質疑応答

b) : コーピングシナリオに基づいて体験談を話し合う形式 


\section{4. 測定用具}

本研究では，情報への満足度に関する介入効 果を検討するために，教育セッションおよびコ ーピング技能訓練のセッションで扱ったテーマ に関する情報，すなわち，1）乳がんに関する医 学的情報, 2) 再発および再発不安に関する情報, 3）がんによるストレスに関する情報，4）がんへ の対処法に関する情報，および5）医療全体の 5 項目への満足度を $100 \mathrm{~mm}$ の線上のいずれかの地 点に示すVisual Analogue Scale(VAS)により測 定した。

\section{5. 分析方法}

ベースライン時のスコア，背景因子，および 医学的因子の 2 群間における比較には $\mathrm{t}$ 検定, $\chi^{2}$ 検定, Mann-Whitney検定のいずれかを行っ た. 介入効果の判定には，ベースライン時のス コアおよび2群間に有意な差の認められた因子で ある化学療法施行の有無を共変量として投入し, 共分散分析 (repeated measures ANCOVA)を行 った。有意な介入効果の認められた項目につい ては，さらに調整済み平均を用いて介入 6 週後 および6ヶ月後の各時点での群間の差を検討する 事後テストを行った。なお，全ての分析はSAS 統計パッケージ ( SAS Institute, Cary, NC, U.S.A.)を用いて行った.

\section{結果}

\section{1. 対象の研究参加状況および特徵}

151名の適格者のうち，126名より返答（返答 率 $83 \%$ ）があり，そのうち53名(35\%)が研究へ の参加意思を示した。残る73名は仕事, 育児, 病院までの遠さなどを理由として挙げ参加を拒 否した。53名の参加意思を示した対象のうち 3 名は適格条件を満たさず $(2$ 名：うつ病, 1 名： 再発)に除外したため，50名 (33\%) を研究参加 者として無作為に割り付けた (介入群 25 例，対 照群25例).

研究参加者 50 名全てがベースライン時および 介入 6 週後のアセスメントを完了したが，6ヶ月 のフォローアップ期間中に 4 名 $(8 \%)$ が脱落した (図1)。脱落理由は, 介入群においてはフォロ
ーアップ期間中の調查協力の拒否 1 例，夫の自 殺による高度のうつ状態のために調查不可能 1 例，対照群においては再発による調查協力の拒 否1例，他の部位のがん(子宮がん)の発症によ る治療入院のため調査の継続不可能 1 例であっ た。 なお，脱落 4 名と調查完了者 46 名の間では, 背景因子，医学的因子，およびベースライン時 のアウトカムに有意な差は認められなかった。

介入群, 対照群の特徵を表 2 に示す. 介入群 において化学療法を施行したものの割合が有意 に高かった $\left(\chi^{2}=5.13, \mathrm{p}=.02\right)$ が，その他の背 景因子および医学的因子においては 2 群間に有 意な差は認められなかった。また，各情報への 満足度と背景および医学的因子との関連を調へ たところ，5項目すべての満足度と年齢との間に 有意な関連 $(\mathrm{r}=0.40, \mathrm{p}=.004 ; \mathrm{r}=0.32$, $\mathrm{p}=.02 ; \mathrm{r}=0.42, \mathrm{p}=.002 ; \mathrm{r}=0.31, \mathrm{p}=.03$; $\mathrm{r}=0.38, \mathrm{p}=.007)$ が認められたが, 他の背景因 子および医学的因子と各情報への満足度との間 に関連は見られなかった。

\section{2. 情報への満足度に関する介入効果}

情報への満足度に関する介入の効果を表 $3 に$ 示す。ベースライン時には 5 項目の満足度に 2 群 間の差は認められなかった。

介入の効果に関しては, ベースライン值を共 変量とし，6週後および6ヶ月後の值を従属変数 とした repeated measures ANCOVAを行った結 果, 乳がんに関する医学的情報, がんによるス トレスに関する情報，がんへの対処法に関する 情報，および医療全体の4項目においてグループ 間に有意な差が認められた $(\mathrm{F}=4.66, \mathrm{p}=.04$ ； $\mathrm{F}=26.22, \mathrm{p}=.0001 ; \mathrm{F}=30.45, \mathrm{p}=.0001 ; \mathrm{F}=$ $12.84, \mathrm{p}=.0009)$. すなわち, 介入群におけるこ れら4項目についての満足度は，6週間の介入に より，対照群に比べて6ヶ月間にわたり有意に改 善した.

次に，有意な改善を示した各項目に対して， どの時点においてグループ間に有意な差が生じ たのかを調べるために，2群間の調整済み平均の 差の検定を 6 週後および 6 ケ月後のそれぞれの時 点において行った。乳がんに関する医学的情報 においては6週後に有意な差 $(\mathrm{p}=.02)$, がんによ 


\begin{tabular}{|c|c|c|c|}
\hline & $\begin{array}{c}\text { 介入群 } \\
\mathrm{N}=25(100 \%)\end{array}$ & $\begin{array}{c}\text { 対照群 } \\
\mathrm{N}=25(100 \%)\end{array}$ & 值 \\
\hline & 平均 $(\mathrm{SD})$ & & \\
\hline 年齢 & $52.6(6.8)$ & $54.3(7.5)$ & NS \\
\hline 術後経過期間（月） & $\begin{array}{l}9.4(4.4) \\
\mathrm{N}(\%)\end{array}$ & $9.2(3.8)$ & NS \\
\hline 雇用状況 & & & NS \\
\hline フルタイム & $10(40)$ & $11(44)$ & \\
\hline パートタイム & $4(16)$ & $2(8)$ & \\
\hline 無職 & $11(44)$ & $12(48)$ & \\
\hline 婚姻状況 & & & NS \\
\hline 既婚 & $22(88)$ & $20(80)$ & \\
\hline 未婚／離婚／死別 & $3(12)$ & $5(20)$ & \\
\hline 娘の有無 & $16(64)$ & $15(60)$ & NS \\
\hline $\begin{array}{l}\text { 未成年の子の有無 } \\
\text { 閉経 }\end{array}$ & $3(12)$ & $4(16)$ & NS \\
\hline 閉経後 & $12(48)$ & $14(56)$ & NS \\
\hline 術式 & & & NS \\
\hline 全切除 & $18(72)$ & $17(68)$ & \\
\hline 部分切除 & $7(28)$ & $7(28)$ & \\
\hline その他 & $0(0)$ & $1(4)$ & \\
\hline 組織異型度 & & & NS \\
\hline 1 & $1(4)$ & $2(8)$ & \\
\hline 2 & $12(48)$ & $13(52)$ & \\
\hline 3 & $11(44)$ & $10(40)$ & \\
\hline 不明 & $1(4)$ & $0(0)$ & \\
\hline リンパ節転移陽性（n1またはn1+） & $12(48)$ & $16(64)$ & NS \\
\hline 化学療法施行 & $17(68)$ & $9(36)$ & 0.02 \\
\hline 放射線療法施行 & $7(28)$ & $8(32)$ & NS \\
\hline 内分泌療法(タモキシフェン)施行 & $8(32)$ & $10(40)$ & NS \\
\hline がん家族歴有り & $10(40)$ & $16(64)$ & NS \\
\hline 病期 & & & NS \\
\hline I & $5(20)$ & $2(8)$ & \\
\hline II & $19(76)$ & $21(84)$ & \\
\hline III & $1(4)$ & $2(8)$ & \\
\hline
\end{tabular}

年齢および術後経過期間の分析： $\mathrm{t}$ 検定 病期の分析：Mann-Whitney検定 その他の分析： $\chi^{2}$ 検定 $\quad \mathrm{NS}=$ not significant

るストレスに関する情報においては6週後，6ヶ 月後ともに $(\mathrm{p}=.0001 ; \mathrm{p}=.004)$, がんへの対処 法に関する情報においても6週後，6ヶ月後とも に $(\mathrm{p}=.0001 ; \mathrm{p}=.0006)$ ，また医療全体において も 2 時点ともに $(\mathrm{p}=.003 ; \mathrm{p}=.004)$ 有意な群間差 を示した。

なお，介入群の 3 グループ間および対照群の 3 グループ間に，いずれの項目においても有意な 差は認められなかった。

\section{考察}

本研究では，6週間という短期の教育的グルー プ介入は初発乳がん患者の情報および医療全体
への満足度を改善し，その効果は6ヶ月間持続 することが示された，以下，それぞれの項目に おける介入効果について順に考察する。

最初に，乳がんに関する医学的情報への長期 的な介入効果が示された結果の解釈を行う。予 備調査において 6 割の参加者が病期別の再発率 や生存期間といった数值で示される医学的情報 は望まないと指摘した(Fukui 2000a)ため, 教育 セッションにおける医学的情報の提供を Q \& A 方式とし，またグループ間で提供する情報内容 の均一化をはかるために乳がんに関する医学的 情報のパンフレット（国立がんセンター情報委員 会提供)を配布した．多くの情報を得ることで不 安をます患者がいること(Mills 1979)，また，情 


\begin{tabular}{|c|c|c|c|c|c|}
\hline \multirow[b]{3}{*}{ アウトカム (レンジ $)$} & \multicolumn{3}{|c|}{ 時点 } & \multicolumn{2}{|c|}{ 介入の効果 } \\
\hline & $\begin{array}{c}\text { ベースライン* } \\
\mathrm{n}=50 \\
(介=25, \quad \text { 対 }=25)\end{array}$ & $\begin{array}{c}\text { 6週間後 } \\
\mathrm{n}=50 \\
(介=25, \quad \text { 対 }=25)\end{array}$ & $\begin{array}{c}6 \text { ケ月後 } \\
\mathrm{n}=46 \\
(介=23, \text { 対 }=23)\end{array}$ & \multicolumn{2}{|c|}{ グループ間 } \\
\hline & 平均 (SD) & 平均 (SD) & 平均 $(\mathrm{SD})$ & $\mathrm{F}^{* *}$ & $p$ \\
\hline $\begin{array}{l}\text { 乳がんに関する医学的情報 } \\
\text { 介入群 }\end{array}$ & $\begin{array}{l}(0-100) \\
46.9(19.4)\end{array}$ & $61.7(17.8)$ & $60.6(17.1)$ & \multirow{2}{*}{4.66} & \multirow{2}{*}{.04} \\
\hline 対照群 & $49.0 \quad(20.3)$ & $51.9(21.2)$ & $54.1 \quad(17.3)$ & & \\
\hline $\begin{array}{l}\text { 再発および再発不安に関す } \\
\text { 介入群 }\end{array}$ & $\begin{array}{r}\text { 一情報 }(0-100) \\
36.4 \quad(20.8)\end{array}$ & $50.1(20.7)$ & $49.0 \quad(22.6)$ & \multirow[b]{2}{*}{2.26} & \multirow[b]{2}{*}{.14} \\
\hline 対照群 & $39.5(21.0)$ & $41.6 \quad(22.0)$ & $48.0 \quad(20.7)$ & & \\
\hline $\begin{array}{l}\text { がんによるストレスに関す } \\
\text { 介入群 }\end{array}$ & $\begin{array}{r}\text { 一情報 }(0-100) \\
40.5(18.1)\end{array}$ & $67.5(16.8)$ & $56.3(16.6)$ & \multirow{2}{*}{26.22} & \multirow{2}{*}{.0001} \\
\hline 対照群 & $42.5(21.9)$ & $41.9(19.9)$ & $43.4 \quad(19.5)$ & & \\
\hline $\begin{array}{l}\text { がんへの対処法に関する情 } \\
\text { 介入群 }\end{array}$ & $\begin{array}{l}\text { 報 }(0-100) \\
36.5(19.8)\end{array}$ & $75.5(14.0)$ & $60.3(18.1)$ & \multirow{2}{*}{30.45} & \multirow{2}{*}{.0001} \\
\hline 対照群 & $48.7(24.7)$ & $45.2(22.1)$ & $43.6(22.1)$ & & \\
\hline $\begin{array}{l}\text { 医療全体 }(0-100) \\
\text { 介入群 }\end{array}$ & $64.2(18.9)$ & $78.0 \quad(19.5)$ & $73.3(18.1)$ & \multirow{2}{*}{12.84} & \multirow{2}{*}{.0009} \\
\hline 対照群 & $69.9(18.7)$ & $69.0(22.0)$ & $66.8(21.7)$ & & \\
\hline
\end{tabular}

*両群間のベースライン值に統計的有意差なし（t-testによる）

**ベースライン值および化学療法施行の有無を補正したrepeated measures ANCOVAによるF 統計量

報を拒否する患者にとっては情報が少ない方が 心配の程度が低い(Miller 1983)ことが指摘され ていることから，Q＆A形式の講義および欲し い情報だけを取り出して読むことができるパン フレットの配布は，参加者各自のニーズに見合 った情報提供を行っていくための有効な方式で あることが本結果により示唆されたと言える。 この手法による医学的情報の提供は乳がんの専 門医でなくても可能であるため，看護職が行う 情報支援の形態として適用していくことができ ると考える.

次に，がんによるストレスおよびがんへの対 処法に関する情報について，予備調査において6 割の参加者がストレスや再発不安への対処法な どの心理学的情報の不足を指摘した (Fukui 2000a) ため, 本調查では教育セッションにおい て心理学的情報の提供に時間を割くとともに, 教育セッションとコーピング技能訓練のセッシ ヨンとのテーマに関連性を持たせた介入を実施
した。その結果，ストレスおよびコーピングと いった心理学的情報への満足度に対して長期間 の強力な介入効果が示された. 乳がん患者は数 多くの心理社会的負担を持ち，これらに対処す る支援の必要性が先行研究により指摘されてい る (Spiegel 1997)ことから, 本介入は, 乳がん患 者の長期にわたる心理社会的負担の軽減，およ び効果的ながんへの対処法の習得のために有効 な看護支援となることが示されたと言える。

再発および再発不安に関する情報については， 再発そのものより再発不安の成り立ちとその取 り組み方についての情報提供を重視した介入を 行ったが，再発および再発不安に関する情報へ の満足度に対する介入効果は示されなかった。 初発乳がん患者にとって重大な心配事は再発で あると指摘されていること (Lasryら 1992 ; Fredette 1995 ; Ferrellら 1996), また本研究の対象 は国立がんセンターという病院の特徽上, 各患 者に対する再発のリスクが主治医より告知され 
ていること (Imoto 1997) から，再発リスクが高 いと告げられている本研究の対象は再発に対す る不安を特に高度に抱えていたと推察される。 このような対象にとっては教育およびコーピン グ技能訓練において再発および再発不安に関す るテーマを1回のみ取り扱うだけでは不十分であ ると考えられ，Imotoら (1998) が提案するよう に，密度の濃い長期間の介入が必要であるかも しれない. 今後, 初発乳がん患者の抱える再発 不安を軽減するための支援方法についての検討 を重ねていくことががん医療に携る看護職の課 題として提示されたと言える.

医療全体への満足度に関しては，ベースライ ン時の值（レンジ0-100）は他の情報への満足度 4 項目が40前後であるのに対し 65 前後と高かっ たものの，短期間の教育的グループ介入により 医療全体への満足度が長期にわたり改善した。 これは，患者の医療への満足は医療者・患者間 のコミュニケーションに関連するという報告 (Hogbinら 1989）があることから，本介入で扱 った ‘医療者との関係”についてのコーピング 技能が参加者により効果的に習得され，参加者 と医療者とのコミュニケーションが実際に改善 した結果，医療全体への満足度が上昇した可能 性が考えられる。医療者・患者間のコミュニケ ーションを良好に行っていくためのコーディネ 一ターとしての役割が期待される看護職 （Fawzy 1995）にとって，本結果は，医療者・ 患者間のコミュニケーションの改善を目的とし た看護支援としても本介入が有効な方策となる 可能性を示したと言えよう.

本研究はサンプルの偏りおよび少ないサンプ ル数といった限界を有するが, 教育的グループ 介入ががん患者の情報への満足度を改善するの に有効であることを我が国において初めて実証 した点で意義深いと考える。欧米においては， がん医療に従事する看護職が心理社会的サポー 卜を実践的に提供することへの期待が高まり， かつ具体化されてきている（Johnson 1982 ; Fawzy 1995 ; Roberts 1995 ; McArdle ら 1996). 我が国においても，本研究で用いた教育的グル ープ介入ががん患者に対する有用な看護支援と して発展していくことが期待される.

\section{謝辞}

本研究は, 平成 $9 \sim 10$ 年度厚生省がん研究助 成金（9-31），および山路ふみ子専門看護教育研 究助成基金からの援助を受けて行われた。

本研究の実施にあたりご指導・ご助言いたた きました東京大学大学院医学系研究科地域看護 学分野前教授金川克子先生，同分野教授村嶋幸 代先生, 国立がんセンター研究所支所精神腫瘍 学研究部内富庸介先生, 岡村仁先生, 久賀谷亮 先生，神谷昌枝氏，小池眞規子氏，中西達郎先 生, ならびに国立がんセンター東病院乳腺外科 井本滋先生に深謝いたします。また，研究にご 協力いただいた対象者の皆様に厚く御礼申し上 げます。

\section{文献}

Bottomly A (1997) : Where are we now? Evaluating two decades of group interventions with adult cancer patients. J Psychiatr Mentl Hlth Nurs, 4, 251-65.

Fallowfield LJ, Baum M, Maguire GP (1986) : Effects of breast conservation on psychological morbidity associated with diagnosis and treatment of early breast cancer. $\mathrm{Br}$ Med J, 293, 1331-34.

Fallowfield LJ, Hall A, Maguire GP (1990) : Psychological outcomes of different treatment policies in women with early breast cancer outside a clinical trial. Br Med J, 301, 57580.

Fawzy FI, Cousins N, Fawzy NW (1990) : A structured psychiatric intervention for cancer patients: I.Changes over time in methods of coping and affective disturbance. Arch Gen Psychiatr, 47, 720-25.

Fawzy FI, Fawzy NW (1994) : A structured psychoeducational intervention for cancer patients. Gen Hosp Psychiatr, 16, 149-92.

Fawzy NW (1995) : A psychoeducational nursing intervention to enhance coping and affective state in newly diagnosed malignant melanoma patients. Cancer Nurs, 18, 427-38. 
Ferrell BR. Grant M. Funk B (1996) : Quality of life in breast cancer. Cancer Practice, 4, 331-40.

Fredette SL (1995) : Breast cancer survivors: concerns and coping. Cancer Nurs, 18, 3546.

Fukui S, Kamiya M, Koike M (2000a) : Applicability of a Western-developed psychosocial group intervention for Japanese patients with primary breast cancer. Psycho-Oncology, 9, 169-77.

Fukui S, Kugaya A, Okamura H (2000b) : A psychosocial group intervention for Japanese women with primary breast carcinoma: A randomized controlled trial. Cancer, 89, 1026-36.

Ganz PA, Shag CA, Fred C (1996) : Breast cancer survivors: psychosocial concerns and quality of life. Breast Cancer Res Treat, 38, 183-99.

Goldberg JA, Scott RN, Davidson PM (1992) : Psychological morbidity in the first year after breast surgery. Eur J Surg Oncol, 18, 327-31.

Goldon WA, Freidenbergs I, Diller L (1980) : Efficacy of psychosocial intervention with cancer patients. J Consult Clin Psychol, 48, 743-59.

Greer S, Moorey S, Baruch JD (1992) : Adjuvant psychological therapy for patients with cancer: a prospective randomized trial. $\mathrm{Br}$ Med J, 304, 675-680.

Hogbin B, Fallowfield LJ (1989) : Getting it taped: The 'bad news' consultation with cancer patients. Br J Hosp Med, 41, 330-33.

Imoto S (1997) : Feasibility of adjuvant chemotherapy for breast cancer patients. Jpn J Clin Oncol, 27, 310-15.

Imoto S, Jitsuiki Y (1998) : Detection of the first recurrence during intensive follow-up of breast cancer patients. Jpn J Clin Oncol, 28, 597-600.

Johnson J (1982) : The effects of patient educa- tion course on persons with a chronic illness. Cancer Nurs, 5, 117-23.

季羽倭文子（1998）：がん告知後のサポートプ ログラム, がん看護学, 三輪書店, pp 96102.

厚生省統計情報部 (1999)：「人口動態統計」

Landis S, Murray T, Bolden S (1998) : Cancer statistics, 1998. A Cancer Journal For Clinicians, 48, 6-29.

Lasry JC. Margolese RG (1992) : Fear of recurrence, breast-conserving surgery, and the trade-off hypothesis. Cancer, 69, 2111-5.

Massie MJ, Holland JC, Straker N (1993) : サイ コオンコロジー38章心理療法的介入, メデ イサイエンス社, pp 417-30.

McArdle JM, George WD, McArdle CS (1996) : Psychological support for aptients undergoing breast cancer surgery: A randomized study. Br Med J, 312, 813-17.

Meyer TJ, Mark MM (1995) : Effects of psychosocial intervention with adult cancer patients: a meta-analysis of randomized experiments. Health Psychol, 14, 101-08.

Meyer TJ, Mark MM (1996) : Statistical power and implications of meta+analysis for clinical research in psychosocial oncology. J Psychosom Res, 41, 409-13.

Miller SM (1983) : Interacting effects of information and coping style in adaptating to gynecologic stress. J Personal Soc Psychol, 45, 223-36.

Mills RT (1979) : Information choice and reaction to stress. J Personality Soc Psycholgy, 37, 608-20.

Ong LML, De Haes JCJM, Hoos AM (1995) : Doctor-patients communication: A review of the literature. Soc Sci Med, 40, 903-18.

Ong LML, Visser MRM, Lammes FB (2000) : Effect of providing cancer patients with the audiotaped initial consultation on satisfaction, recall, and quality of life: A randomized, double-blind study. J Clin Oncol, 18, 3052-60. 
プリメド社編 (1996)：全国患者会障害者団体要 覧，プリメド社，pp 200-05.

Rees CE, Bath PA (2000) : The information needs and source preferences of women with breast cancer and their family members: a review of the literature published between 1988 and 1998.J Adv Nurs, 31, 83341.

Roberts J (1995) : The effectiveness and efficacy of health promotion in speciality clinic care. Med Care, 33, 892-905.

Sheard T, Maguire P (1999) : The effect of psychological interventions on anxiety and depression in cancer patients: results of two mata-analyses. Br J Cancer, 80, 1770-80.

Spiegel D (1997) : Psychosocial aspects of breast cancer treatment. Semin Oncol, 24, S1-36-S1-47.

Tamura T, Lau A (1992) : Connectedness versus separateness: Applicability of family therapy to Japanese families. Fam Proc, 31, 319-40.

Tsuda H, Akiyama F, Kurosumi M (1998) : Establishment of histological criteria for high-risk node-negative breast carcinoma for a multi-institutional randomized clinical trial of adjuvant therapy. Jpn J Clin Oncol, 28, 486-91.

Walker LG, Eremin O (1996) : Psychological assessment and intervention: future prospects for women with breast cancer. Semin Surg Oncol, 12, 76-83. 